\title{
PENINGKATAN KETERAMPILAN BERBICARA BAHASA INGGRIS DENGAN MEDIA PERMAIAN ULARTANGGA
}

\author{
I Ketut Wahya \\ Sekolah Menengah Pertama Negeri 1 Bangli
}

\begin{abstract}
According to the Curriculum Based Competency, the objective of learning English is to master the communication competence, it means that the students should be able to express their idea and their feeling in communication activities even in oral or in written. So, English teacher should be able to assist their students to become effective participants in real life communication. We need to help them in any ways that motivate them to use the language as many times as possible. The main goal of teaching English to the secondary school is to developed their language skills; listening, speaking, reading and writing. Based on experience as English teacher at secondary school (SMP Negeri 1 Bangli), most students still poor using the language in communication even in oral or in written. This problem appear because of some factors like; lack of vocabulary, poor in grammar, lack of practicing use the language, and boring because the teacher's strategy in teaching is monotone, and never use media. To solve those problems, the writer try to do the Classroom Action Research. The research focus on developing speaking skill using media Snake and Ledger game.
\end{abstract}

Key words: competency,speaking,learning english

\section{PENDAHULUAN}

Penguasaan bahasa Inggris dan bahasa asing lainnya dapat dikatakan merupakan persyaratan utama bagi keberhasilan individu, masyarakat dan bangsa Indonesia dalam menjawab tantangan jaman pada tingkat global. Penguasaan bahasa dapat diperoleh lewat berbagai program, tetapi program pembelajaran bahasa Inggris khususnya di sekolah tampaknya merupakan sarana utama bagi sebagian anak Indonesia karena bahasa Inggris adalah bahasa Internasional.

Pada hakekatnya belajar bahasa adalah belajar berkomunikasi dengan bahasa lisan dan tulisan. Dalam mempelajari suatu bahasa, kebermaknaan merupakan hal yang sangat penting. Kebermaknaan tersebut berdasarkan konteks, baik konteks kebahasaan maupun konteks situasi. Kegiatan pembelajaran akan lebih bermakna bagi siswa jika hal itu berhubungan dengan kebutuhan siswa, pengalaman, minat, tata nilai dan masa depannya.Menurut kurikulum berbasis kompetensi dalam belajar bahasa inggris tingkat SMP terdapat empat keterampilan berbahasa yang dalam kurikulum dijabarkan dalam kompetensi 
tindak tutur untuk bahasa lisan dan retorika dalam bahasa tulis. Kompetensi ini secara garis besar dijabarkan dalam keterampilan reseptif (listening dan reading) dan keterampilan produktif (speaking dan writing)

Namun kenyataan di lapangan menunjukan bahwa pembelajaran bahasa Inggris di Indonesia masih sangat jauh dari tujuan penguasaan keterampilan makro yang didinginkan. Lulusan sekolah menengah belum mampu menggunakan bahasa ini untuk berkomunikasi.Berdasarkan pengalaman penulis mengajar bahasa inggris di SMP Negeri 1 Bangli,dan interviu secara informal dengan guru-guru bahasa inggris di kabupaten Bangli, terungkap bahwa guru belum memiliki gambaran yang jelas tatacara mengajarkan speaking. Pembelajaran Speaking menurut pandangan guru adalah membuat siswa berlatih menghafalkan dialog, mendemontrasikan dialog sebanyak mungkin. Namun bagaimana tata cara membuat siswa dapat berkomunikasi dengan bahasa inggris yang benar tidak diketahui oleh guru. Dengan kata lain, guru dalam kegiatan pembelajaran Speaking, guru pada umumnya tidak memberikan bekal dan ruang gerak yang cukup pada siswa sehingga siswa mampu mengungkapkan buah pikirannya dalam berkomunikasi yang benar. Hal ini tercermin hasil belajar siswa pada keterampilan berbicara yang rendah,dimana pada ujian praktik berbicara rata -rata kurang dari 50, sebagian besar siswa tidak mampu berkomunikasi menggunakan bahasa inggris yang sangat sederhana. Dari data tersebut dapat disimpulkan bahwa kemampuan siswa berbicara menggunakan bahasa inggrismasih relatif rendah. Hal itulah yang mendorong penulis untuk melakukan penelitian yang bertujuan untuk meningkatkan kemampuan siswa dalam berbicara menggunakan bahasa inggris.

Berdasarkan pengamatan-pengamatan tersebut diatas, nampaknya ada permasalahan yang perlu mendapatkan penanganannya. Rendahnya kemampuan siswa dalam kemampuan berbicara dalam bahasa inggris, terutama dalam mengungkapkan gagasan, semua ini disebabkan oleh beberapa faktor antara lain, rendahnya motivasi siswa belajar bahasa inggris, takut melakukan kesalahan dalam ucapan (pronunciation) dan struktur bahasa, masih rendahnya penguasaan kosa kata. Faktor lainnya adalah strategi yang digunakan oleh guru dalam pembelajaran bahasa inggris kurang bervariasi sehingga terkesan monoton yang menyebabkan siswa merasa bosan, atau guru jarang menggunakan media dan permainan yang bisa membuat senang belajar bahasa Inggris.Dengan demikian, permasalahan yang akan dipecahkan melalui penelitian ini berkaitan dengan kurang bersistemnya guru dalam pengajaran keterampilan berbicara. Berdasarkan uraian tersebut diatas, maka tujuan dari penelitian ini adalah; (1) Bagi guru, dengan dilaksanakannya penelitian ini, guru diharapkan 
dapat secara bertahap mengetahui strategi pembelajaran yang tepatdan bervariasi serta mampu memotivasi siswa untuk belajar bahasa inggris; (2) Bagi siswa, untuk meningkatkan motivasi belajar guna mencapai

ketuntasan belajar terutama pada keterampilan berbicara; (3)Bagi sekolah, hasil penelitian ini diharapkan memberi sumbangan yang bermanfaat khususnya bagi sekolah, terutama dalam rangka perbaikan pembelajaran bahasa inggris pada akhirnya meningkatkan mutu pendidikan.

Adapun hipotesis tindakan adalah, dengan menggunakan media permainan ular tangga mampu memotivasi dan meningkatkan kemampuan siswa untuk mengungkapkan ungkapan transaksional dan interpersonal yang sangat sederhana, sehingga dapat meningkatkan keterampilan berbicara bahasa Inggris siswa.

\section{METODE PENELITIAN}

Sesuai dengan tujuan penelitian ini yang berupaya untuk meningkatkan kemampuan berbicra bahasa inggris, maka penelitian ini menggunakan rancangan Penelitian Tindakan Kelas(classroom action and research)(Elliot,1983 dan Kemmis et al,1982). Maksudnya adalah penelitian yang berupaya menggabungkan dua permasalahan utama, yaitu peningkatan dalam pelaksanaan program keterampilan Speaking, dan peningkatan pemahaman langkahlangkah yang ditempuh untuk peningkatan kualitas pengajaran keterampilan Spaeking, dengan menintegrasikan dalam serangkaian siklus tindakan. Penelitian ini menggunakan 2 siklus,yaitu siklus pertama terdiri dari 1)penyusunan program pembelajaran (planing),2) penyajian pembelajran (action), 3) penilaian pembelajaran (evaluasi) dan 4)analisa data (refleksi). Pada siklus kedua dilaksanakan dengan memperhatikan evaluasi dampak implementasinya pada siklus I. Berdasarkan hasil evaluasi ini, disusunlah rancangan baru untuk diimplementasikan pada siklus II (kedua) yang tahapannya sama seperti pada siklus I. Penelitian ini berlangsung selama 3 bulan dari bulan september sampai dengan bulan nopember 2008, yang terbagi menjadi dua siklus dengan alokasi waktu 6(enam) m9inggu untuk siklus I, dan 4 (empat) minggu untuk siklus II. Setiap akhir siklus diakhiri dengan refleksi.

\section{Subyek Penelitian :}

Penelitian Tindakan Kelas ini dilaksanakan di SMP Negeri 1 Bangli, pada siswa kelas VII b semester 1 tahun 2008/2009,dengan jumlah siswa 35 orang yang terdiri dari laki-laki 15 orang dan perempuan 20 orang. 


\section{Tahap-tahap Penelitian :}

\section{a. Penyusunan Program Pembelajaran (Planning) :}

Program pembelajran merupakan rangkaian kegiatan awal dalam persiapan suatu pembelajaran. Penyusunan program pembelajaran perlu dilakukan agar proses pembelajaran yang tengah dilaksanakan dapat terarah dan dapat mencapai tujuan yang diharapkan. Dalam penyusunan program pembelajaran bahasa inggris kelas VII dilakukan beberapa langkah berikut ini:

1. Menganalisa Standar Isi berupa pemetaan Standar Kompetensi dan Kompetensi Dasar.

2. Mengembangkan Kompetensi Dasar ke Indikator

3. Mengembangkan Silabus

4. Mengembangkan Rencana Pelaksanaan Pembelajaran (RPP)

5. Menyusun skenario pembelajaran

6. Menyusun Instrumen penilaian

7. Menyiapkan alat-alat yang dibutuhkan (dadu, kartu/gambar,kertas manila) Setiap kelompok diberi alat permainan dan dijelaskan teknis kegiatan kelompok.

\section{b. Penyajian Program Pembelajaran (Acting) :}

Berdasarkan rumusan masalah bahwa kemampuan siswa dalam berbicara bahasa inggris masih rendah, maka pemecahan permasalahan tersebut ialah melalui tindakan dengan menggunakan media permaian Ular tangga yang diemplementasikan dalam proses belajar mengajar yang bertumpu pada langkah-langkah yang tertuang pada RPP.Adapun langkahlangkah pelaksanaan proses pembelajaran adalah sebagai berikut :.

1. Kelas dibentuk dengan beberapa kelompok, setiap keompok terdiri dari 5 (lima) orang.

2. Setiap kelompok diberikan satu set permainan ular tangga yang terdiri dari :

dadu, batu(tanda) setiap peserta, kartu yang berisi nomor dan dibaliknya berisi suruhan, dan alas bermain. 
3. Sebelum dimulai, anggota kelompok harus melakukan undian untuk menentukan giliran melempar dadu siapa yang pertama, kedua, dan seterusnya.

4. Setiap anggota mendapat giliran untuk melempar dadu, dan melangkahkan batu miliknya sesuai dengan nomor yang muncul di dadu.

5. Setelah melangkahkan batu tanda peserta sesuai dengan angka yang di dadu maka peserta wajib mengambil kartu sesui dengan nomor yang ada pada kotak berhenti, lalu peserta melaksanakan perintah sesuai dengan suruhan yang terdapat di kartu. (contoh: Apabila kartu berisi suruhan untuk menanyakan alamat maka dia harus bertanya kepada seluruh pemain tentang alamat mereka dengan bahasa Inggris dan pemain menjawab dengan bahasa inggris juga).

6. Pada akhir permainan setiap peserta dihitung beberapa kali dia mendapat kesempatan berbicara, dan beberapa kali dia tidak mampu berbicara.

\section{c. Penilaian Pembelajaran (evaluasi) :}

Untuk mengukur keberhasilan pembelajaran berbicara bahasa inggris dengan menggunakan media permainan ular tangga, penilaian dilakukan dengan dua cara yaitu; penilaian proses termasuk afektif, dan penilaian hasil belajar.

\section{Penilaian Proses Pembelajaran}

Penilaian proses pembelajaran dilakukan saat pembelajaran berlangsung, Guru mengukur sampai seberapa jauh tingkat keberhasilan pembelajaran melalui pengamatan terhadap minat, dan perhatian siswa dalam mengikuti pembelajaran, maupun respon yang diberikan dalam menanggapi serta menafsirkan pertanyaan dan pernyataan guru. Penilaian dilakukan dengan menggunakan cek list pada lembar pengamatan selama proses pembelajaran. Siswa diamati dengan melakukan pengamatan kondisi kelompok, aktivitas kelompok, aktivitaas individu, inter dan antar kelompok, kreatifitas, inovasi, kerjasama, dengan format penilaian .

Pembelajaran dapat dikatakan berhasil apabila anak memiliki minat dan perhatian cukup tinggi dan berpartisipasi aktif dalam mengikuti proses pembelajaran

\section{Penilaian Hasil Belajar}

Penilaian hasil belajar dilaksanakan apabila pembelajaran telah selesai dilaksanakan. Penilaian ini dapat dilakukan dengan tes lisan dengan fokus penilaian pada komponen berikut; Ucapan (pronunciation), Tata bahasa (grammar), Kebermaknaan 
(meaningfulness),Fungsi (fuction),Komunikasi (communication),Kepercayaan diri siswa,Improvisasi

\section{d. Refleksi (Reflecting) :}

Refleksi dari hasil tindakan keberhasilan dan kekurangannya sebagaimana tersebut diatas menjadi bahan pertimbangan dalam menentukan tindakan pada siklus kedua. Jenis instrumen yang digunakan dalam penialain proses dan hasil belajar adalah :

1. Catatan hasil pengamatan (observasi) kegiatan siswa yang diamati oleh 2 (dua) orang guru bahasa Inggris

2. Ulangan harian

3. Produk berdasarkan hasil wawancara secara individual

Berdasarkan hasil pengamatan dan penilaian terhadap pelaksanaan tindakan pada siklus pertama,diketahui bahwa siswa belum maksimal menggunakan bahasa Inggris dalam permainan, dimana masih banyak siswa menggunakan bahasa Indonesia . Siswa menggunakan bahasa Inggris hanya pada saat bertanya jawab sesuai dengan kartu yang mereka peroleh. Dari sisi kompetensi siswa masih banyak menggunakan grammar yang tidak tepat, ucapan masih belum sempurna, siswa masih malu-malu, dan dalam bermain masih didominasi oleh beberapa siswa pada setiap kelompok.

Berdasarkan hal tersebut diatas pada kegiatan siklus II, siswa selanjutnya diajak melakukan permainan yang sama ,tetapi lebih bebas mengungkapkan pikiran,idea, dan perasaanya dalam mendeskripsikan gambar (gambar binatang,buah-buahan,bangunan)yang mereka dapatkan pada kartu permainan. Kompetensi yang dikembangkan adalah kemampuan mendekripsikan gambar secara lisan.

\section{HASIL DAN PEMBAHASAN}

Setelah tindakan penelitian dilakukan evaluasi untuk mengukur keberhasilan pembelajaran dengan instrument berupa tes secara lisan. Tujuannya adalah untuk mengetahui tingkat keberhasilan proses belajar dalam menggunakan media permainan ular tangga, dalam meningkatkan keterampilan berbicara bahasa Inggris. Hasil yangdiperoleh oleh siswa dapat dilihat berdasarkan pada perubahan sikap positif siswa, dengan indikator sebagai berikut :

\section{Keberhasilan :}

a. Perhatian siswa ketika bermain di masing-masing kelompok sangat tinggi 
b. Siswa mampu mengungkapkan dengan bahasa lisan yang sederhana

c. Siswa memiliki keberanian untuk berbicara menggunakan bahasa Inggris

d. Siswa mampu bertanya jawab dengan menggunakan bahasa Inggris .

e. Siswa mampu berbicara bahasa Inggris dengan ucapan ,tatabahasa,fungsi yang tepat,serta memiliki kepercayaan diri,dan kelancaran berkomunikasi.

f. Hasil belajar yang diperoleh siswa diatas standar ketuntasan belajar minimal (65)

\section{Kekurangan/Kegagalan}

a. Perhatian siswa rendah ketika bermain di kelompoknya

b. Ada peserta yang masih Pasif atau tidak pernah berbicara

c. Tidak mampu bertanya jawab dengan menggunakan bahasa Inggris

d. Dalam bermain masih banyak menggunakan bahasa Indonesia

e. Hasil belajar yang diperoleh siswa dibawah standar ketuntasan belajar minimal (65)

Berdasarkan indikator tersebut diatas, seorang siswa dinyatakan berhasil (tuntas) jika telah mendapatkan nilai minimal 65 (standar ketuntasan belajar minimal), sedangkan bagi siswa yang memperoleh hasil belajar dibawah 65 dianggap belum berhasil (belum tuntas). Jika secara klasikal siswa yang mendapat nilai diatas atau sama dengan 65 sudah mencapai 85 $\%$ keatas berarti kegiatan belajar mengajar dinyatakan berhasil.

\section{Hasil Proses Pembelajaran}

Setelah dilaksanakan serangkaian tindakan penelitian proses pembelajaran pada siklus I dan siklus II, dan berdasarkan hasil observasi, catatan harian dari guru yang membantu pelaksanaan tindakan ini diproleh gambaran seperti yang dilaporkan berikut ini.

Dari hasil pengamatan memang proses komunikasi masih berlangsung secara sederhana, namun betapapun sederhananya percakapan siswa, perlu dihargai karena apabila tidak pernah diekspresikan atau dilatih seperti dalam permainan ular tangga, akan sulit bagi siswa. Keterampilan berbicara memerlukan kebiasaan,keberanian dan berperan aktif.

Berikut ini paparan hasil kegiatan yang telah dilakukan melalui pengamatan dan penilaian terhadap proses pembelajaran dan hasil belajar siswa melalui ulangan harian berbentuk lisan, serta non tes berupa angket. 
Tabel 1. Minat,Perhatian, dan Berperan aktif siswa dalam keterampilan berbicara bahasa inggris.

Aspek yang diamati (\%)

\begin{tabular}{|l|l|l|l|l|}
\hline Siklus & Minat & Perhatian & Berperan aktif & Rata-rata \\
\hline I & 94,33 & 90,01 & 92,50 & 92,23 \\
\hline II & 97,70 & 97,31 & 98,20 & 97,73 \\
\hline
\end{tabular}

Berdasarkan tabel hasil pengamatan tersebut diatas dapat disimpulkan sebagai berikut a.Minat

Dari analisis data berdasarkan kehadiran di kelas saat pembelajaran bahasa inggris, diperoleh hasil sebanyak 94,33\% pada siklus I dan sebanyak 97,70\% pada siklus II, ini menujukan bahwa kegiatan pembelajaran bahasa inggris dengan menggunakan media permainan ular tangga dapat meningkatkan minat siswa terhadap pembelajaran bahasa inggris

\section{b. Perhatian}

Dari analisis data berdasrkan partisipasinya dalam kelompok, serta menyelesaikan tugas, diperoleh hasil 90,01\% memiliki perhatian baik pada siklus I, dan 97,31\% memiliki perhatian baik pada siklus II. Dari hasil ini dapat diinterpretasikan bahwa kegiatan pembelajaran bahasa inggris dengan menggunakan media permainan ular tangga dapat meningkatkan perhatian siswa dalam pembelajaran bahasa inggris

\section{c.berperan aktif}

Dari analisis data berdasarkan keaktifan bertanya dan menjawab, dan keberanian berbicara, diperoleh hasil 92,50\% berperan aktif pada siklus I, dan 98,20\% pada siklus II. Dari hasil ini dapat diinterpretasikan bahwa kegiatan pembelajaran bahasa inggris dengan menggunakan media permainan ular tangga dapat meningkatkan peran aktif dan keberanian siswa berbicara bahasa inggris.

\section{Hasil Akhir Pembelajaran}

Setelah diadakan pengolahan data dari hasil yang dikumpulkan baik pada saat penilaian proses (on going proses) maupun pada penilaian hasil belajar. Peniaian hasil belajar dilakukan dengan praktik berbicara dengan melakukan tanya jawab dengan guru sejenis, 
dimana setiap guru mendapat tugas untuk bertanya jawab dengan 8 orang siswa.Dari hasil yang dikumpulkan ternyata ada perbedaan yang signifikan seperti terlihat pada table penilaian dan pengamatan pada proses pembelajaran. Keadaan siswa sebelum diberi inovasi pembelajaran berupa permainan ular tangga dan setelah diberikan permainan ular tangga baik pada siklus I, maupun pada sklus II. Disamping itu berdasarkan angket yeng diisi oleh siswa menunjukan adanya minat siswa belajar bahasa Inggris sangat tinggi. Untuk mengetahui peningkatan hasil belajar siswa dapat dilihat pada table dibawah ini :

Tabel 2. Nilai rata-rata siswa dari tes hasil belajar (\%)

\begin{tabular}{|l|l|l|l|l|}
\hline Tes awal & Tes siklus I & Tes siklus II & Peningkatan & Ket \\
\hline 53,3 & 89,9 & 98,2 & 22,45 & \\
\hline
\end{tabular}

Berdasarkan data diatas tes hasil belajar dapat diketahui nilai rata-rata kelas pada tes awal berada dibawah $60 \%$, kalau dilihat data hasil tes siklus I (P-0) cukup baik dan mengalami peningkatan. Berdasarkan data hasil belajar siswa pada tes I (P-1) sebagian besar siswa masih lemah dalam ucapan (pronunciation dan ,menggunakan tata bahasa yang benar. Maka pada kegiatan siklus II lebih difokuskan pada latihan ucapan dan tata bahasa. Pada hasil penilaian tes II (P-2) cukup baik dan mengalami peningktan. Hal tersebut mengindentifikasikan keberhasilan pembelajaran bahasa inggris dengan menggunakan media permainan ular tangga.

Keberhasilan penggunaan media permainan ular tangga dalam proses pembelajaran dapat dilihat dengan membandingkan nilai rata-rata kelas tes awal (P-0)dengan nilai hasil tes siklus I (P-1) dan hasil penilaian tes siklus II (P-2)

Tabel 3.Penentuan Ketuntasan Belajar Minimal Siswa

\begin{tabular}{|c|c|c|c|c|c|}
\hline \multirow[t]{2}{*}{ No. } & \multirow[t]{2}{*}{$\begin{array}{l}\text { Kompetensi } \\
\text { Dasar/ }\end{array}$} & \multirow{2}{*}{$\begin{array}{l}\text { Standar } \\
\text { Ketuntasan } \\
\text { Belajar } \\
\text { Minimal }\end{array}$} & \multicolumn{3}{|c|}{$\begin{array}{l}\text { Pencapaian ketuntasan } \\
\text { (Jumlah siswa) }\end{array}$} \\
\hline & & & $<65 \%$ & $65-84 \%$ & $85-100 \%$ \\
\hline Siklus I & KD 1.2. & 65 & 2 siswa & 19 siswa & 14 siswa \\
\hline Siklus II & KD 1.3 & 65 & 2 siswa & 17 siswa & 16 siswa \\
\hline
\end{tabular}


Berdasarkan tabel diatas bahwa dari 35 siswa yang belum mencapai ketuntasan belajar minimal adalah sebanyak 2 orang siswa (5,7 \%),sedangkan yang lainnya sebanyak 33 orang siswa $(94,3 \%)$ sudah mencapai ketuntasan belajar.

Dengan demikian, kegiatan pembelajaran dengan menggunakan permainan ular tangga sebagai media pembelajaran, telah berhasil meningkatkan kompetensi komunikatif bahasa inggris, pada keterampilan berbicara.

\section{SIMPULAN DAN SARAN}

\section{Simpulan}

Mencermati hasil kegiatan yang telah dilaksanakan melalui permainan ular tangga ,maka dapat diambil kesimpulan sebagai berikut :

a. Bahwa strategi pembelajaran melalui media permainan ular tangga dalam pembelajaran bahsa Inggris ternyata mampu meningkatkan kompetensi komunikatif dan prestasi belajar.

b. Melalui permainan ular tangga siswa merasa senang terhadap pelajaran bahasa Inggris yang ditunjukan dengan kesungguhan siswa mengikuti proses pembelajaran, sehingga meningkatkan motivasi belajar.

c. Dengan permainan ular tangga siswa dapat menggunakan ungkapan komunikatif dengan lancar, sepontan dan alami, rasa percaya diri siswa meningkat dalam upaya meningkatkan keterampilan berbicara

\section{Saran}

a. Penggunaan media permainan ular tangga masih banyak kekurangan dan keterbatasan, oleh karena itu diharapkan guru mampu mengembangkannya lebih kreatif, inovatif sehingga hasilnya lebih baik.

b. Media pembelajaran yang baik bukan yang mahal harganya atau yang moderen, tetapi mampu berfungsi sebagai sarana untuk mencapai tujuan pembelajaran.

\section{UCAPAN TERIMA KASIH}

Ucapan terima kasih penulis sampaikan kepala sekolah dan rekan-rekan di SMP Negeri 1 Bangli yang telah memberikan pembinaan, bantuan dan dorongan baik moril maupun materiil, sehingga tulisan ini dapat diseleswaikan. 


\section{DAFTAR PUSTAKA :}

Aswan Z. 2002. Strategi Belajar Mengajar. Jakarta: PT Rineka Cipta.

Aqib, Z.2004. Karya Tulis Ilmiah, Yrama Widya, Bandung

Bobbi De Porter, 2004. Quantum Teaching. Bandung: PT Mizan Pustaka

Bobbi De Porter, 2004. Quantum Learning. Bandung: PT Mizan Pustaka

Depdiknas, 2004. Modul Landasan Filosofis-Teoritis Pendidikan Bahasa Inggris. Jakarta: Depdiknas

Depdiknas, 2004. Modul Media Pembelajaran Bahasa Inggris. Jakarta: Depdiknas.

Depdiknas, 2004. Modul Penilaian Pembelajaran Bahasa Inggris. Jakarta: Depdiknas

Depdiknas, 2004. Modul Ungkapan-ungkapan Bahasa Inggris Untuk Pengajaran. Jakarta: Depdiknas

Depdiknas, 2004. Modul Sistematika Kurikulum Bahasa Inggris 2004 dan Pengembangan Silabus. Jakarta: Depdiknas 